\title{
ARTICLES
}

\section{Reshaping Private International Law in China: The Statutory Reform of Tort Conflicts}

\author{
Zhengxin $\mathrm{Huo}^{*}$
}

This article reviews the statutory reform of Chinese private international law from the perspective of tort conflicts which concludes that notwithstanding the significant improvement, the new Private International Law Act of China are fraught with various defects. In the field of tort, Article 44 are problematic in three aspects: first, the key term 'habitual residence' lacks an objective definition; second, the rationality of an automatic preference to the law of the common habitual residence over the lex loci delicti is open to doubt; third, there is little, if any, practicability to introduce the notion that the parties may choose the applicable law after the tort has happened. Moreover, there are a number of defects or problems with Article 45, Article 46 and Article 50 of the Act, respectively. What's more, the Act neglects some other important types of torts which call for special treatment, say, unfair competition, and environmental pollution, nuclear damage and traffic accidents. In the end, the article puts forward the corresponding suggestions for improvement.

\section{Keywords}

China's New Private International Law Act, Tort Conflicts, Lex Loci Delicti, Double actionability, Common Habitual Residence, Party Autonomy, Particular Torts

* Associate Professor of Law at the School of International Law of China University of Political Science and Law ("CUPL"); Deputy Director of the Institute of Private International Law of the CUPL. B.A.(Anhui Univ.), M.A. (Guangxi Univ.), Ph.D. in Law(Wuhan Univ.). The article is a part of the project sponsored by the China National Social Sciences Fund, Project No. 10CFX077. The author may be contacted at: huozhengxin@hotmail.com / Address: No. 25 Xitucheng Road, Haidian District, Beijing, 100088, P.R. China. 


\section{Introduction}

The People's Republic China adopted its first statute on Private International Law titled, "Act on the Application of Laws on Foreign-related Civil Relationships" (hereinafter Private International Law Act) at the seventeenth Session of the Standing Committee of the Eleventh National People's Congress( "NPC") on October 28, 2010. It came into force on April 1, 2011.1 The enactment of the Private International Law Act is a historic event in Chinese legislative history, as it indicates China has modernized its conflict-of-law rules after many years of unremitting efforts made by legislators and scholars. More importantly, it represents a major political accomplishment in establishing "a socialist legal system with Chinese characteristics.” 2

The Private International Law Act contains 52 articles arranged under eight chapters, with headings that are indicative of their respective scope. ${ }^{3}$ Among those 52 articles, there are four articles that deal with torts. In Chapter IV, Article 44 lays down the main rules on the law applicable to a tort claim, Articles 45 and 46 provide the choice-of-law rules for two particular torts respectively, i.e., product liability and internet defamation; In Chapter VII, Article 50 specifies the choice-of-law rules for infringement of intellectual property. Moreover, it is worth emphasizing that Article 51 in Chapter VIII states ambiguously that Article 146 of the General Principles of the Civil Law of the People's Republic of China ("GPCL") shall be replaced by the relevant articles of the Private International Law Act. 4

1 See Zhonghua Renmin Gongheheguo Shewai Minshi Falvguanxi Shiyongfa [Act on the Application of Laws on Foreign-related Civil Relationships/Private International Law Act] (2010); Zhonghua Renmin Gongheguo Zhuxi Ling [Order of the President of The People's Republic of China], No 36, available at http://www.npc.gov.cn/huiyi/cwh/ 1116/2010-08/28/content_1593162.htm (last visited on Jan. 2, 2012).

2 At the 15 ${ }^{\text {th }}$ National Congress of the Communist Party of China, the rule of law principle was established as a fundamental principle for the administration of the country. In order to implement the principle the Party put forward a legislative plan pursuant to which the socialist legal system with Chinese characteristics would be shaped up by 2010. To ensure the accomplishment of the legislative plan, the National People's Congress, China's supreme legislature, has accelerated legislation after 2005. See Zhongguo Gongchandang Dishiwuci Quanguo Daibiaodahui Wenjian Huibian [Collection of Documents of the Fifteenth National Congress of the Communist Party of China], 5-6 (1997). See also Zhengxin Huo, China's Codification of Conflicts Law: Latest Efforts, 51 SEouL L.J. 279, 283 (2010).

3 Chapter I(General Provisions), Chapter II(Civil Subjects), Chapter III(Marriage and Family), Chapter IV(Succession), Chapter V(Property), Chapter VI(Obligations), Chapter VII(Intellectual Property), Chapter VIII(Supplementary Provisions). For detailed discussion of the Private International Law Act, see Zhengxin Huo, An Imperfect Improvement: The New Conflict of Laws Act of the People's Republic of China, 60 InT' L \& CoMP. L.Q. 1065-1093 (2011).

4 The GPCL was adopted at the $4^{\text {th }}$ Session of the Sixth National People's Congress on April 12, 1986, coming into force on January 1, 1987. It is still effective, assuming a prominent role in the area of civil law in China. The GPCL has devoted an entire chapter to regulating the conflict of laws (i.e., Chapter VIII, Application of Law in Foreignrelated Civil Relations), where only Article 146 is dealing with tort. See Zhonghua Renmin Gongheguo Minfa Tongze ("GPCL") art. 146 (1986). 
As carefully scrutinizing the above articles, one can observe that Chinese private international law in respect of tort is undergoing a fundamental transformation: First, the double actionability rule embodied in Article 146 of the GPCL was abolished. Second, and more strikingly, the Private International Law Act introduces party autonomy to the field of tort. Third, the Act switches to establish habitual residence, rather than nationality or domicile, as the connecting factor to determine the lex personalis. Last, but not least, particular rules for product liability, internet defamation, and infringement of intellectual property are laid down by the Private International Law Act. Furthermore, Article 51 of the Private International Law Act indicates that among the tort choice-of-law rules that have existed in various separate laws prior to the date of commencement of the Private International Law Act, only Article 146 of the GPCL was abolished. It therefore follows that the tort choice-of-law rules included in the Maritime Act and the Civil Aviation Act, remain unaffected by the new statutory code. 5

As such, the purpose of this article is two-fold. First, it provides an examination of the statutory reform of private international law regarding tort conflicts that has happened in China. Second, after summarizing problems concerning the tort choice-oflaw rules have surfaced in this process, it puts forward suggestions for improvement. This article is composed of four parts including Introduction and Conclusion. Part II examines the tort choice-of-law rules in Chinese law before the enactment of the new Private International Law Act. Part III provides an in-depth exegesis of the tort choiceof-law rules contained in the new Act, and critically analyzes the problems thereof. Part IV concludes the discussion with suggestions to improving the specific tort choice-oflaw rules as well as Chinese private international law legislation as a whole.

\section{Choice of Law in Tort prior to the Private International Law Act}

\section{A. The Main Rules on Torts}

Before the enactment of the Private International Law Act, the main rules on the law applicable to a tort claim were laid down by Article 146 of the GPCL which provided that:

5 Zhonghua Renmin Gongheguo Haishangfa [Maritime Act] art. 273 (1993); Zhonghua Renmin Gongheguo Minyong Hangkongfa [Civil Aviation Act] art. 189 (1996). 
With regard to compensation for damages resulting from a tortious act, the lex loci delicti shall be applied. If both parties are nationals of the same country or domiciled in the same country, the law of their own country or of their place of domicile may also be applied.

An act committed outside the People's Republic of China shall not be treated as a tortious act if under the law of the People's Republic of China it is not a tortious act.

Additionally, in order to implement the GPCL, the Supreme People's Court, in its capacity as interpreter of the application of law as prescribed by the Organic Law of the People's Courts, ${ }^{6}$ issued the "Opinions of the Supreme People' s Court on Implementing the General Principles of Civil Law of the People's Republic of China" (hereinafter Opinions on the GPCL) in 1988.7 Given the definition of the lex loci delicti is somewhat ambiguous, the Supreme People's Court set forth in Article 187 of the Opinions on GPCL that: 8

The lex loci delicti may refer either to the law of the place where the tortious act was committed or to that of the place where the harm of the act occurred and that People's Courts may select either in case where these two laws are different.

The above articles indicated that Chinese conflicts law in tort before the Private International Law Act established a single general rule, containing two limbs, and a single exception thereto. Thus, the combined effect of Article 146 (1) of the GPCL and Article 187 of the Opinions on GPCL was to establish a general rule whose operation depended on the existence or otherwise of a domicile or a nationality common to the parties. If both parties were of the same citizenship or domicile, the lex partriae or the lex domicilii may apply. If no such common citizenship or domicile existed, the tort was governed by the lex loci delicti which included either the law of the place of occurrence of the tort or that of the place of the occurrence of the results of the tort. Then, Article 146 (2) of the GPCL provided an exception which meant that, in order for an act committed outside the PRC to be actionable in the PRC, it must necessarily be regarded as a tort in accordance with the domestic Chinese law. This exception was regarded by Chinese

6 The Supreme People's Court may interpret points of law arising from the concrete application of law in the adjudicative work of the courts. This type of interpretation is known as 'judicial interpretation.' Documents of judicial interpretation issued by the Supreme People's Court have general binding force although they are not legislation archives in nature. See Feng Lin, Constitution Law in China 221 (2000); Albert Hung-Yee Chen, AN InTRoduction to the Legal System of the PEOPLE's Republic of China 118-128 (3rd ed. 2004).

7 See Zuigao Renmin Fayuan Guanyu Shiyong Zhonghua Renmin Gongheguo Minfatongze Ruogan Wenti de Yijian [Supreme People's Court Opinions on Application of the General Principle of Civil Law of the People's Republic of China], 92 Zuigao Renmin Fayuan Gongbao [Bulletin of Supreme People's Court] 22 (1988).

8 Id. art. 187. 
scholars as a Chinese version of double actionability. ${ }^{9}$

\section{Lex Loci Delicti}

The lex loci delicti theory (the application of the system of law of the place where the tort was committed) is the orthodox doctrine in classic private international law which was prevailing in both civil law countries and some common law countries, such as the United States and Australia, until the first part of the twentieth century. 10

The theory, dating back to the fourteenth century, is originally derived from the ancient Latin axiom "locus regit actum" which means the law of the locality regulates the thing to be done. 11 In the first half of the twentieth century, it is further endorsed by the vested rights theory. ${ }^{12}$ Adherents suggest that the lex loci delicti reflects and protects the legitimate and reasonable expectations of the respective parties. Furthermore, it is contended that the jurisdiction in which the tort was committed is the place that has the greatest interest in striking a reasonable balance among safety, cost, and other factors pertinent to the design and administration of a system of tort law.13

Chinese legislators enacting the GPCL accepted the lex loci delicti theory for the similar reasons who believed that the adherence to this theory in general avoided egregious forum shopping and led to certain, predicable and uniform result.14 However, judicial practice suggested it was not infrequent that the tortious act and the harm of which the plaintiff complained occurred in different jurisdictions. Accordingly, the Supreme People's Court empowered the courts to choose a law of either place at discretion should this situation occur.

Nonetheless, it should be noted that unlike the laws of many other civil law countries, 15 Chinese law at this stage failed to provide any guideline for judges to follow when they have to choose one law between the law of the place of occurrence of the tort and that of the place of the occurrence of the results of the tort; arbitrary selections and

9 See GuojI Sifa [Private International LaW] 368 (Xianglin Zhao ed. 2011).

10 C.G.J. Morse, Choice of Law In Tort: A Comparative Study, 32 Am. J. Comp. L. 51, 90 (1984); Alan ReEd, AngloAmerican Perspectives on Private International Law 380 (2003); Dan Jerker B. Svantesson, Private INTERNATIONAL LAW AND INTERNET 310 (2007).

11 Hessel Yntema, The Historic Bases of Private International Law, 2 AM. J. CoM. L.297, 304 (1953).

12 See generally Perry Dane, Vest Righted, 'Vestedness' and Choice of Law, 96 YALE L.J. 1191, 1194-95 (1987); Lea Brilmayer, Rights, Fairness and Choice of Law, 98 YALE L. J. 1277, 1281 (1989).

13 Spinozzi v. Sherator Corp, 174 F.3d 842 (7th Cir. 1999). See also Zhengxin Huo, Choice of Law in Tort a Chinese Approach, 4 J. CAMBRidge STUD. 82, 86 (2009).

14 See Guoj Sifa [Private International LaW] 318-319 (Jin Huang ed. 2004).

15 E.g. German courts hold that the most favourable law would apply to the victims in this case; Swiss private international law provides that if the defendant's act occurs in one State, and harm occurs in another State, the latter's law is applicable if the defendant could have foreseen that harm would occur in that State. See Morse, supra note 10 at 59, 75. See also REED, supra note 10, at 435; Symeon Symeonides, Rome II and Tort Conflicts: A Missed Opportunity, 56 AM. J. Comp. L. 173, 189, 222 (2008). 
inconsistent decisions were, therefore, almost inevitable. Indeed, judicial practice in China suggested that the People's Courts under this circumstance tended to choose the law which would be more favorable to the Chinese parties. The following two decisions may serve as illustrative examples.

In Tokizaki v. Beijing Hongyun Tianwaitian Restaurant Co. Ltd. Case,16 decided in 2001, the plaintiff, a Japanese national, was injured in an assault by the employees of the defendant, a Chinese company, located in Beijing. The plaintiff brought an action in Beijing and sought compensation in the amount of 4,096,333.55 yuan (RMB) pursuant to Japanese tort law. The trial judge acknowledged that: (1) the alleged wrongful act was committed in China, and the damage was suffered primarily in Japan and continued to occur there; (2) Chinese tort law differed from Japanese tort law in assessing damages resulting from a wrongful act, and the latter provided a higher level of compensation. The judge went on to reason that as he was entitled to choose either Chinese law or Japanese law in such legal scenario under Article 187 of the Opinions on the GPCL, he thus chose Chinese law, i.e., the law where the wrongful act was committed, as the governing law at his discretion. Regrettably, no detailed reasoning or further explanation in support of the choice was provided in the judgment. As a result, the judgment was rendered pursuant to the relevant Chinese law, under which the award of damages to the plaintiff was reduced to $229,612.85$ yuan (RMB), a sum which was much less than he had expected.

In Gansu Highway Administration v. Yokohama Rubber Co. Ltd. Case,17 the plaintiff alleged that a defective tire manufactured by the defendant, Japan's third-largest tire maker, caused the death of its four employees. The plaintiff specified that four of its employees, including a driver, left Lanzhou on business in an automobile owned by the plaintiff. When the car was driven along a highway in Shaanxi Province, one of the car tires exploded which led to the accident, claiming the lives of the four. Gansu Highway Administration thus brought the action against Yokohama Rubber Co. Ltd. in Xi' an Intermediate People's Court, seeking compensation in the amount of 557,000 yuan (RMB) under Japanese Product Liability Law on the ground that it was the law of the place where the defective tire was manufactured. Nonetheless, the defendant argued that Chinese law, as the law of place where the accident happened, should apply. The judge of Xi' an Intermediate People's Court reasoned that under Article 146 of the GPCL, the dispute in question should be governed by lex loci delicti. Moreover, pursuant to Article 187 of the Opinions on the GPCL, either Chinese law or Japanese law may be selected as the applicable law, insofar as the injury occurred in China while the alleged

16 See (2001)-Erzhong-Min-Chuzi-No.3311 [The first judgment of Beijing Second Intermediate People's Court].

17 See (2003)-Xizhong-Jing-Chuzi-No.074 [The first judgment of Xi' an Intermediate People's Court]. 
defective tire was manufactured in Japan. The judge emphasized that due weight should be given to the argument of the plaintiff in the present case, as its employees, the victims of the alleged defective products, was the weaker party whose legitimate interests should be protected. In this light, the judge chose Japanese Product Liability Law as the applicable law.

In both cases, the tortious act and the harm of which the plaintiff complained occurred in different jurisdictions; however, different People's Courts chose different laws under the same conflicts rule, depending on which law would benefit the Chinese litigants. Such decisions demonstrated that the lack of guideline for selecting law in case that the place where tort was committed differed from that of the occurrence of the results of the tort has led to too much elasticity and flexibility in the application of the lex loci delicti, which undermined uniformity, predictability and certainty that private international law purports to safeguard.18

\section{The Common Personal Law}

As indicated earlier, Article 146 of the GPCL stated that where the persons who inflicted the injury and the victim were nationals or domiciliaries of the same state, the law of that State may displace the lex loci delicti. The rationale for applying common personal law is based on the likelihood that where such a law exists, it will be more closely connected with the parties than the lex loci delicti, or its application better reflects the expectations of the parties.19 Indeed, recent private international law codifications and international conventions have adopted the notion that the common personal law of the parties normally prevails over the lex loci delicti. This notion is implemented either through a common domicile rule, 20 or through an exception from the lex loci rule. The exception is phrased either in common-domicile or common habitual residence language, 21 or in common-nationality language. 22 Thus, preference for the common

18 Yongping Xiao, Zhongguo Chongtufa Lifa Wenti Yanjiu [A Study on the Legislative Issues of China’s Confucts LAw] 341 (1996). See also Huo, supra note 13, at 87-88.

19 Morse, supra note 10 , at 91.

20 See Bunesgesetz ber das Internationale Privatrecht [Federal Code of Private International Law] Dec. 18, 1987, SR 291, art. 133 (Switz.); 64 R.S.Q. 3126 (1991)(Can.); Hague Convention on the Law Applicable to Products Liability, art. 5, Oct. 2, 1973, 1056 U.N.T.S. 187.

21 See 2001 Act Regarding the Conflict of Laws on Torts of 11 Apr. 2001, stb. 2001, 190 art. 3(3) (Neth.); Einfü hrungsgesetz zum Bürgerlichen Gesetzbuche ("EGBGB") [Introductory Act to the Civil Code], May 21, 1999, BGBI. I at 1026, art. 40(2) (F.R.G.); Regulation (EC) No. 864/2007 on the Law Applicable to Non-Contractual Obligations (Rome II), arts. 4(2), 5(1), 6(2) \& 9, 2007 O.J. (L 199) 40.

22 See Legge di riforma del sistema italiano di dritto internazionale privato e processuale [Law Reforming the Italian System of Private International Law] of May 31, 1995, Gazz. Uff. no. 218, art. 62 (Italy). See also Symeon Symeonides, Oregon's New Choice-of-Law Codification for Tort Conflicts: An Exegesis, 88 OR. L. Rev. 963,1001 (2009). 
personal law over the lex loci delicti by the GPCL seems to reflect similar developments in contemporary conflicts law around the world. 23

However, it should be noted that unlike the laws of many countries which provide a systematic and automatic preference of the common personal law over the lex loci delicti, 24 Article 146 of the GPCL stated clearly that the application of the common personal law was discretionary rather than mandatory; differently expressed, judges were entitled to apply either the lex loci delicti or the common personal law of the parties. The reason for employing an alternative reference rule is that though the common personal law is likely to be more closely connected with the tort or better reflected the legitimate expectations of both parties, it is by no means the case that common personal law must in fact be so. In certain cases, the automatic displacement of the lex loci delicti in favor of the common personal law has been proved to unjustified.25 What is more, in contrast to the laws of many other countries which provide an exception in favor of the law of another country which has a manifestly closer connection with the tort, 26 the GPCL did not include such exception. Therefore, it was submitted that the alternative reference rule adopted by Article 146 of the GPCL was a necessary arrangement to avoid the injustice that automatic displacement of the lex loci delicti by the common personal law may produce.

\section{The Double Actionability Rule}

Under Article 146(2) of the GPCL, in order for an act committed outside People's Republic of China to be recognized as a tort in the PRC, it must necessarily be regarded as a tort under the domestic Chinese law. Apparently, this was the reflection of the double actionability rule. According to some Chinese scholars, Article 146(2) of the GPCL was based on the consideration that implementing open door policy often involved laws of many capitalist countries which often had strict liability principles in dealing with tort and which allowed the definition of tort to include a very broad range of acts; the double actionability rule would limit the adverse impact of the absolute liability doctrine in tort or of the broad coverage of tort being developed in the Western legal system. 27

Though such consideration was not irrational, the reflection of the double

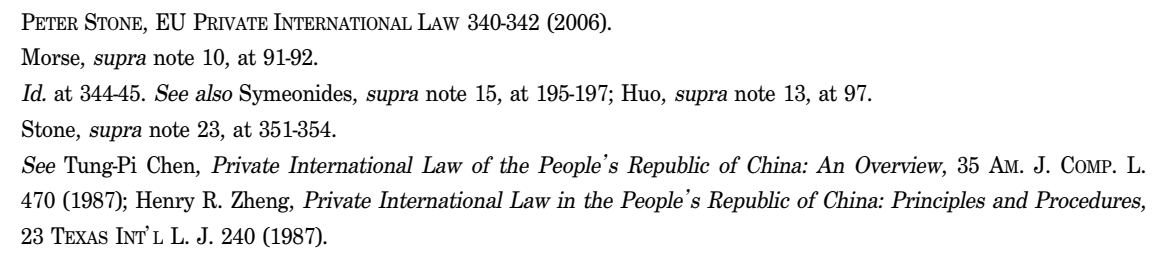


actionability rule in the GPCL had invited a lot of criticisms especially since the late 1990s. Many Chinese scholars have questioned the merits and rationality of the incorporation of this common law rule and rejected it as an outmoded remnant of the past. The debate on the double actionability rule among Chinese scholars will be introduced in more detail in Part III A.

\section{B. Some Particular Torts}

Though the GPCL contained only one article on the choice-of-law rules for tort in general, some other Chinese laws prior to the enactment of the Private International Law Act lay down particular rules for certain torts. The Maritime Act of the People's Republic of China, effective as of July 1, 1993, makes the following conflicts rules for maritime torts in Article 273.28

The law of the place where the infringing act is committed shall apply to claims for damages resulting from collision of ships.

The law of the place where the court hearing the case is located shall apply to compensation for damages resulting from collision of ships on the high seas.

If the colliding ships belong to the same country, the law of the flag state shall apply to claims for damages resulting from collision between them, irrespective of the place where the collision occurs.

Adopted on October 30, 1995, the Civil Aviation Act of the People's Republic of China contains conflicts rules for aerial torts, providing in Article 189 as follows: ${ }^{29}$

The law of the place where the infringing act is committed shall apply to claims for damages to the third party on the ground by civil aircraft.

The law of the place where the court hearing the case is located shall apply to claims for damages to a third party on the high seas surface by civil aircraft from the air.

Echoing Article 146(1) of the GPCL, Article 273 of the Maritime Act, and Article 189 of the Civil Aviation Act confirm the status of lex loci delicti as the general rule; additionally, given the particularities of maritime and aerial torts, the two articles provide special conflicts rules respectively in case application of the lex loci delicti is not possible or appropriate.

Under Article 273 of the Maritime Act, the lex loci delicti is supplemented with one substitute and one exception. Pursuant to Article 273(2), where the collision occurs on

\footnotetext{
28 Maritime Act, supra note 5, art. 273.

29 Civil Aviation Act, supra note 5, art. 189.
} 
the high seas, the lex fori shall be applicable. This substitute is self-explanatory: as the high seas are subject to no State's jurisdiction, the lex loci delicti is of no availability, the lex fori, the law of the place of jurisdiction chosen by the victim would, therefore, be the governing law. 30 However, both Article 273(1) and (2) shall be displaced if the ships wear the same flag in which case the law of the flag shall be applied. The exception is based on the presumption that the law of flag in this case usually has a closer connection with such collision than the lex loci delicti, and that the rule in favor of the law of the flag States reflects and protects the legitimate expectations of both parties.31

Pursuant to Article 189 of the Civil Aviation Act, claims for damages to the third party by civil aircraft is governed by: (1) the lex loci delicti if tort occurs on the ground; or (2) by the lex fori if tort occurs on the high seas, as it is impossible to determine the lex loci delicti in this case. However, a careful perusal of Article 189 of the Civil Aviation Act will reveal two problems: first, the article fails to provide the governing law in case where two aircrafts collide with each other; second, if literally interpreted, the article does not cover the situation where damages to the third party by civil aircraft occurs on the surface of the territorial waters.

As noted above, among the tort choice-of-law rules that have existed before the enactment of the Private International Law Act, only Article 146 of the GPCL was abolished. Then, Article 273 of the Maritime Act and Article 189 of the Civil Aviation Act will continue to apply to the issues that fall within their respective scope.

\title{
III. Choice of Law in Tort under the Private International Law Act
}

\begin{abstract}
Abolishing Article 146 of the GPCL, the Private International Law Act prescribes relatively elaborate conflict rules for torts which contain both rules for torts in general and particular rules for certain torts. Generally speaking, the incorporation of various new choice-of-law rules in tort by the Private International Law Act is a response to the fact that more and more foreign-related tort cases are adjudicated by the Chinese People's courts, and the existing conflicts rules were unable to provide proper solutions. 32
\end{abstract}

\footnotetext{
HUANG, supra note 14, at 338-339.

Id. at 339. See also Huo, supra note 13, at 89.

2 Huo, supra note 3, at 1089.
} 


\section{A. The Main Rules on Torts}

The main choice-of-law rules on torts are provided by Article 44 of the Private International Law Act which applies to most torts. It specifies:

The laws applicable to tort liability shall be the law of the country in which the tortious act is committed. However, where the parties concerned have their habitual residence in the same country, the tort liability shall be governed by the law of that country. If the parties choose the applicable law by agreement after the tort occurred, their agreement shall prevail.

Under Article 44 (1) of the Private International Law Act, tort liability, as a general rule, is governed by the lex loci delicti. However, this rule is subject to two exceptions: (1) if both parties are habitually resident in the same country, the tort shall be governed by the law of that country; (2) if the parties reach an agreement on the applicable law after the tort occurred, the tort is governed by the law chosen by them. Such triple structure manifests that the Chinese legislators take pains to maintain equilibrium between the orthodox doctrine and modern ones: on the one hand, the general rule of Article 44 is nothing but a restatement of the traditional lex loci delicti; on the other hand, the Private International Law Act attempts to substantively reform Article 146 of the GPCL by abolishing the double actionability rule, introducing party autonomy and choosing habitual residence to replace domicile and nationality as the connecting factor to determine the lex personalis. 33

As the lex loci delicti remains to be the general rule, a question naturally arises: where a tortious act and the ensuing damage occur in different places, which one shall be determinant? Though Article 44 per se fails to provide any guiding principle, one can find the solution by virtue of Article 2(2) of the Private International Law Act. Included in Chapter I (General Provisions), Article 2 provides in the second paragraph that a foreign-related civil relationship is governed by the law most connected to it, where neither this Act nor any other law designates the applicable law. 34 Thus, the law keeping the closer connection with tort, between the law of the place of conduct and that of injury, shall be applied under such a circumstance. Compared with the GPCL which did not provide any guideline for courts to choose between the two laws, the Private International Law Act, obviously, represents an improvement.

Another issue which should be mentioned is that the reference made by Article 44 is

See Zhonghua Renmin Gongheguo Shewai Minshi Falvguanxi Shiyongfa: Shiyt yu Fenxi [Understanding Act on

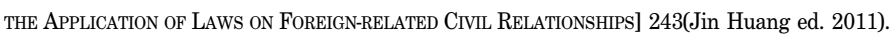

34 Private International Law Act, supra note 1, art. 2. 
always the substantive law of the relevant country. Renvoi is excluded by Article 9, which stipulates that the foreign law applicable to a foreign-related civil relationship does not include the conflicts law of that foreign country. 35

As regards the reform made by the Private International Law Act, there are several points worth drawing attention to. First, the double actionability rule reflected in the GPCL has been abolished. ${ }^{36}$ As mentioned above, Chinese scholars have questioned the merits and rationality of the incorporation of the double actionability rule since the late 1990s. They argued that the rule operated in favor of the defendant and to the disadvantage of the plaintiff, and could lead to absurd and anomalous results; 37 therefore, even in the United Kingdom, the double actionability rule in Phillips v. Eyre Case had been abolished in respect of all torts except defamation committed after May 1, 1996; 38 furthermore, they contended that with the development and improvement of Chinese economy and legal system, the differences between Chinese tort law and the Western tort law were no longer substantive. ${ }^{39}$ In fact, the Tort Liability Act of the PRC enacted in 2009 has incorporated many doctrines in torts developed in the Western legal system. 40 Accordingly, there was neither theoretic justification nor practical necessity for the Chinese law to retain this out-dated rule. For these reasons, they advocated that Chinese law should abolish the rule as soon as possible. 41 In response to their suggestions, the Private International Law Act does not include the out-dated rule.

Second, Article 44 (2) of the Private International Law Act ensures that the law of the country where the parties are habitually resident will prevail over the lex loci delicti. What merits particularly strong emphasis is that habitual residence has been elevated to a fundamental status by the Private International Law Act; or to be more specific, habitual residence, rather than nationality, has been established as the principal connecting factor to determine lex personalis, family law and succession law. 42 There are three reasons for China to deviate from the orthodox position of civil law. 43 First, in a BRIEN, CONFLICT OF LAWS 397-405 (2d ed. 1999).

38 see The Official Home of UK Legislation, available at http://www.legislation.gov.uk/ukpga/1995/42/section/10 (last visited on Mar. 2, 2012).

39 Huo, supra note 3 , at 1089.

40 See Zhonghua Renmin Gongheguo Qinquanzerenfa [Tort Liability Act] (2009).

41 Zhao, supra note 9, at 369. See also ShuANG-YUAN Li, GuoJ Sifa [Private InTERnational LAw] 601-603(2001); Xiao Song, Shuangchong Kesuguize, Jintuizhiji [The Rule of Double Actionability: Stay or Go Away] 1 FALVKEXU [SCIENCE OF LAW] 103-112(2009).

42 Huo, supra note 3 , at 1077.

43 Id. 
globalized world where human affairs freely cross national boundaries, the connection between a person and his nationality is not as close as it used to be. Second, lawsuits are usually brought where parties live, the nexus of habitual residence favors application of the lex fori, whereas reliance on the lex patriae rends to increase foreign law problems. ${ }^{44}$ Third, China comprises more than one jurisdiction, under the model of "One Country, Two Systems"; Hong Kong and Macau possess the status of "Special Administrative Regions" which exercise a "high degree of autonomy" and enjoy independent executive, legislative and judicial power. As a result, there are actually three legal systems that now exist concurrently in China. Hong Kong still retains the common law system inherited as a former British colony, and Macau employs a legal system based on that of Portuguese civil law. Within such a setting, nationality cannot determine the internal law to which a Chinese national is subject. As habitual residence enjoys such a fundamental status in the Private International Law Act, it is not surprising that the law of the country where the parties are habitually resident replaces both the lex partriae and the lex domicilii. 45

Third, and more strikingly, Article 44 (3) of the Private International Law Act gives preference to the law chosen by the parties after the tort has occurred notwithstanding paragraphs 1 and 2.46 The introduction of party autonomy to tort represents a paradigm shift: in tort, achieving the public interests of justice had traditionally been considered to be paramount but adjusting the private interests of the parties is increasingly considered to be also important. 47 The new rule imposes no restriction on the range of legal systems to choose from. Nonetheless, it does not permit a choice before a tort takes place, as the parties usually do not contemplate a future tort, and allowing pre-tort agreements may lead to the consequence that the socially stronger party imposes its unilateral choice on the weaker party. 48

Though Article 44 of the Private International Law Act represents some progress compared with Article 146 of the GPCL, it produces several problems simultaneously, which can be analyzed as follows:

First, despite the vital importance of habitual residence, neither the Private International Law Act nor other Chinese legislation provides a definition of this term.

44 Id. See also Friedrich JuEnger, Choice of LaW AND Multistate Justice 42 (2005)

45 See Zhengxin Huo, Shewaiqinquan Zhizhai de Falvshiyong-yi 7.23 Yongwenxian Tebiezhongda Tielu Jiaotongshiguzhong Waijishangwangchengke de Peichang wei Shijiao [Applicable Law to Torts - A Commentary on the Dispute between the Dead and Injured Foreign Passengers and China's Railway Ministry in the Wenzhou Train Collision of July 23], 6 FASHang Yanjiu [STUdies In LAW \& Business] 12(2011).

46 Private International Law Act, supra note 1, art. 44(3).

47 Koji Takahashi, A Major Reform of Japanese Private International Law, 2 J. PrIvate InT' L L. 311,332 (2006). See also Symeonides, supra note 22, at 993-994.

48 Huo, supra note 3 , at 1089. 
The application of the law of common habitual residence, therefore, depends on the arbitrary interpretation of this term by judges. 49 Given the fundamental status of habitual residence in the Private International Law Act as well as the unsatisfactory judicial environment in China, the author believes that this is a serious defect.

Second, the merit of an automatic preference to the law of the common habitual residence over the lex loci delicti is open to doubt. Certainly, there are many situations in which it seems clear that the law of the common habitual residence should prevail, as it reflects both the most significant relationship and the legitimate expectations of the parties; nevertheless, preference of the common habitual residence is not justified in some other situations. 50 As a matter fact, this is the reason why Article 146 (2) of the GPCL provided that the displacement of the lex loci delicti in favor of the common personal law is in any case a matter of discretion, rather than mandatory, as noted earlier.51 Given Article 44 of the Private International Law Act, like Article 146 of the GPCL, does not include an escape from the common-residence rule, i.e., a closer connection exception, the author submits that the automatic preference given by Article 44 (2) of the Private International Law Act to the common habitual residence is problematic. In this respect, Article 44 (2) of the Private International Law Act is regress, rather than progress vis-à-vis Article 146 (2) of the GPCL.

Last, but not least, the practicability of allowing the parties to choose the applicable law after the tort has happened may be challenged. The reason is almost self-evident; after the tort has occurred, the parties are in a position to know of their rights and obligations. As reasonable persons, they naturally desire to apply the law that would lead to the result more favorable to them. After the occurrence of the tort, each party knows the result of the application of the relevant laws, thus, "the veil of ignorance" is pierced, and it follows that it is very difficult for the parties to reach an agreement at this stage. 52 Such situation is vividly represented by the following case. 53

On July 23, 2011, two high-speed trains collided in the suburbs of Wenzhou, Zhejiang Province, China. Forty people were killed and more than two hundreds were injured, twelve of whom were fatal.54 Among the dead, there were two U.S. citizens and

50 Stone, supra note 23 , at 344-346.

51 Huo, supra note 13 , at 97.

52 Xiao Song, Qinquan Chongtufa Yibanguize Zhiqueli, Jiyu Luoma II yu Zhongguo Qinquan Chongtufa de Duibi Fenxi [On the General Rule of Tort Conflicts, A Comparative Analysis on Rome Convention II and Chinese Tort Conflicts], 3 FAXUEJIA[JURISTS]165-166 (2010).

53 For detailed information of the train accident, see Di Yang, Shengsi Yongwenxian [A Tragedy on the Railway], 28 ZHongGuo Xinwen ZHoukan [CHINA NeWs WeEKLY] 22-26 (2011).

54 The investigation blamed faulty signal systems and mismanagement, available at http://www.gov.cn/ldhd/2011-12/ 28/content_2032218.htm; http://en.wikipedia.org/wiki/Wenzhou_train_collision (all last visited on Jan. 1, 2012). 
one Italian citizen. After the accident, China's Ministry of Railways announced that the families of each victim would be compensated 915,000 yuan (around USD145,000). As regards the compensation to the foreigners who were killed in the train collision, the Ministry of Railways reiterated on various occasions that the families of the foreign victims would be compensated pursuant to the same standard under the Act on the Application of Laws on Foreign-related Civil Relationships of the PRC and the Tort Liability Act of the PRC. 55 Nevertheless, the families of the foreign victims refused to accept the solution offered by the Ministry of Railways who argued that the law of their home country, rather than Chinese law, should be applied. Up to the end of 2011, no agreement had been reported to be reached between the families of the foreign victims on the one hand, and the Ministry of Railways on the other.56 This case graphically illuminates that after a tort happened, each party usually aspires to apply the law to favor its particular condition. It is by no means easy for the parties to reach an agreement on the applicable law. In this sense, the feasibility and necessity of introducing party autonomy to tort in this manner is highly arguable.

\section{B. Particular Torts}

With the increasing complexity of tortious liability, the legislators of many countries today share the view that there is a need to indicate particular conflict rules for particular types of torts apart from providing conflict rules for tort in general. This is the case for Switzerland, Belgium, Spain, Italy, Germany, Austria,57 Japan,58 and European Union's Rome II Regulation, etc.59 The Private International Law Act, in response to such need and the international trend, incorporates special conflict rules for product liability, internet defamation and IPR torts. 60

\section{Product Liability}

In recent years, there have been many cases in China concerning the liability for the harm caused by defective products manufactured in foreign countries. However Chinese People's Courts have not adopted a consistent approach to solving the choiceof-law issues in those cases due to the lack of clear guidance from law. Therefore, it is of

\footnotetext{
55 Huo, supra note 45 , at 12 .

56 Id. at $12-13$.

57 Thomas Graziano, General Principles of Private International Law of Tort in Europe, JAPANESE AND EUROPEAN Private International Law in Comparative Perspective 255 (Jurgen Basedow et al. eds. 2008).

58 Takahashi, supra note 47 , at 329.

59 Rome II, supra note 21 , arts. 5-8.

60 Huo, supra note 3 , at 1090.
} 
considerable significance for the Private International Law Act to provide specific conflict rules for product liability. 61

Article 45 of the Private International Law Act provides that the claims for damages relating to product liability shall be governed by the law of the habitual residence of the victim. However, if the victim chooses the law of the principal place of business of the tort-feasor or that of the place where the damage occurred, or if the tort-feasor did not engage in any soliciting activities in the place in which the victim is habitually resident, the law of the principal business place of tort-feasor or that of the place where the damaged occurred, shall be applied.62

Hence, under Article 45, the applicable law shall be ascertained in the following order of priority. First, if the plaintiff chooses to apply the law of the principal place of the defendant or that of the place where the damage occurred, the choice of the plaintiff shall be respected. Second, if the plaintiff does not choose a law, or his choice is not valid, the applicable law shall be determined according to whether the defendant engaged in soliciting activities in the country where the plaintiff is habitually resident or not. If the defendant did not, then the law of his principal place or that of the place where the damage occurred shall be applied. Third, in case neither of the above situations occurred, the law of the habitual residence of the plaintiff shall be applied.63

Thus, the combined effect of the three limbs of Article 45 is to establish a general rule plus two exceptions; or to be more specific, the law of the habitual residence of the plaintiff shall be applied is the general rule, which is subject to the following two exceptions: (1) if the customers choose to apply the law of the principal place of the defendant or that of the place where the damage occurred, their choice shall prevail; (2) if the defendant did not engage in any soliciting activities in the country where the plaintiff is habitually resident, the law of the principal place of the defendant or that of the place where the damage occurred shall be applied.

Basically speaking, the primary objective of Article 45 is to protect the interests of the consumers, as they are usually the weaker party compared with the manufacturers. Therefore, the claims for damages relating to product liability are generally governed by the law of the habitual residence of the customers, insomuch as they are usually familiar with this law and they will normally expect to be protected under it. If they find that the law of the principal place of the defendant or that of the place where the damage occurred, is more favorable to the protection of their interests, however, they can choose either law to replace the law of their habitual residence.

63 HuANG, supra note 33, at 254. 
Additionally, certainty and reasonable balance of interests are also among the concerns of Article 45.64 Therefore, Article 45(3) ensures that if the defendant did not engaged in any soliciting activities in the country where the plaintiff is habitually resident, the law of the principal place of the defendant or that of the place where the damage occurred shall replace the law of the habitual residence of the customers. The reason underlying this exception is that in the context of Article 45(3), the consumer is referred to as an 'active consumer', rather than a 'passive consumer.' Such a consumer is not eligible for the protection under the law of the country of his habitual residence; it would also be beyond the foreseeabilty of the manufacturer should the law of the habitual residence of the customers be applied in this case. Thus, it concludes that the general rule, together with two exceptions, is a balanced solution in regard to these objectives. 65

However, there is one question which needs to be answered, i.e., which law, between the law of the principal place of the defendant and that of the place where the damage occurred, shall be applied, if the defendant did not engage in any soliciting activities in the country where the plaintiff is habitually resident and the plaintiff did not make a valid choice of law or did not make a choice at all? Regrettably, Article 45 does not contain answer. The only solution seems to be offered by Article 2(2) of the Private International Law Act. As noted above, Article 2(2) provides that a foreign-related civil relationship is governed by the law most connected to it in case of a legal vacuum. 66

\section{Internet Defamation}

Special rule is also considered necessary for defamation via internet, as such torts do not happen in a 'real place'. Under Article 46 of the Private International Law Act, infringements of right of personality, including the right of personal name, portraiture right, privacy, and reputation, via internet or other means, shall be governed by the law of the victim's habitual residence. 67 Therefore, a single law will apply even if the victim's personal right is harmed in more than one jurisdiction. Taking the characteristics of internet defamation into consideration, this rule avoids the complexity of applying different laws to a single, and usually inseparable, tortious act.

The victim's habitual residence is established as the connecting factor for the following reasons. First, as it is often in the place where the victim is habitually resident that his personal right is harmed most seriously, such provision is helpful to protect the

\footnotetext{
64 Id. at $254-256$.

65 Id. at 253 .

66 For a detailed discussion on Article 2(2), see Huo, supra note 3, at 1071-1072.

67 Private International Law Act, supra note 1, art. 46. See also Huo, supra note 3, at 1090.
} 
interests of the victim. Second, it may also provide the alleged tortfeasor a certain degree of predictability. 68

However, there are two problems with Article 46. First, as emphasized earlier, in spite of the importance of habitual residence, neither the Private International Law Act nor any other Chinese legislation provides the definition of this term. The application of Article 46, therefore, depends on the arbitrary interpretation of the term by judges. Second, the wording of Article 46 indicates that it governs infringements of right of personality via the internet or 'other means.' No guidance is, however, given as to the exact meaning of 'other means' used herein. Given the quality of Chinese judges and the legal atmosphere in China is far from perfect, the author submits that the vagueness of Article 46 as to its core concepts would lead to uncertainty and unpredictability in judicial practice. 69

\section{Infringement of Intellectual Property}

Intellectual property rights ("IPRs") have been acknowledged and protected in the PRC since the late 1970s when the Party adopted a new policy of reform opening up to the world. Since joining the World Trade Organization ("WTO"), China has further amended the legal framework of the IPRs and its related laws and regulations to comply with the WTO Agreement on Trade-Related Aspects of Intellectual Property Rights ("TRIPs"). 70 In the existing Chinese law prior to the Private International Law Act, however, there were no conflicts rules for the IPRs which, to a considerable degree, led to the consequence that most Chinese judges and lawyers were not well aware that the disputes involving the IPRs pose conflict-of-law issues.71

In order to correct the lack of understanding and to establish a complete conflict of laws regime, the Private International Law Act has devoted an entire chapter, i.e., major problem is that China is short of the rule of law in general and there is a long way to go for accomplishing the task of building a modern legal system. In particular, judicial corruption has not been effectively checked at the present stage. The removal of Songyou Huang, Vice President of Supreme People's Court in 2008, out of office due to corruption may serve as a typical case. Second, Chinese judges, especially in backward regions, are not well qualified and have not been ready to handle the complicated civil cases involving foreign elements. See ZHENGXIN Huo, Private InTERnational LaW In China 107-108 (2010).

70 China amended the Patent Law in 1992 and 2000, respectively; the Copyrights Law in 2001; the Trademark law in 1993 and 2001, respectively. Despite stronger statutory protection, it has to admit that China continues to be a haven for counterfeiters and pirates. According to one copyright industry association, the piracy rate remains one of the highest in the world. For detailed information, see Protecting Your Intellectual Property Rights in China, available at http://www.mac.doc.gov/China/Docs/businessguides/IntellectualPropertyRights.htm (last visited on Jan. 1, 2011).

71 Huo, supra note 2, at 308 . 
Chapter VII, to regulating the IPRs which consists of three articles, covering the ownership and the content of the IPRs (Article 48), the assignment and the licensed use of the IPRs (Article 49), and the infringement of the IPRs (Article 50). To be more specific, Article 50 provides that:

The tort liability arising from an infringement of an intellectual property right shall be governed by the law of the country where protection is claimed; the parties concerned may also choose the lex fori as the governing law after the tort has happened by agreement.

Similar to the law of many other countries, 72 the Private International Law Act establishes that the lex loci protectionis is the general rule to govern the infringement of an intellectual property right. This is because the law under which an alleged infringement occurs usually has a greater interest in governing the protection of intellectual property. Additionally, in the majority of cases, given the territorial character of intellectual property protection, other law can hardly govern the issue effectively. Therefore, Chinese scholars believe that Article 50 preserves the universally acknowledged principle in favor of the lex loci protectionis and territorial character of an intellectual property right granted or recognized in a given country. ${ }^{73}$

Moreover, it is important to note that Article 50 permits the parties to an IPR tort case to choose the lex fori as the governing law after the tort has happened. This is not only the reflection of a limited party autonomy, but also the manifestation of the legislative intent to expand application of the lex fori.

Nevertheless, one special problem may arise in the following case: if the infringements occur in different countries, and the parties do not reach the agreement on applying the lex fori, should the court apply different laws to what is essentially a single wrong perpetrated by a single infringer? Suppose that a case concerns multiple infringements in different countries, and the claimant has brought proceedings in China, as the country of the infringer's domicile. ${ }^{74}$ In principle, each infringement is a separate wrong, each subject to the law of the country where each infringement occurs - a conclusion required by the lex protectionis rule. Although this is unproblematic in concept, it has serious practical consequences: It may be both unfair and unrealistic to expect the claimant to sue upon each and every infringement, not least because of the cost and delay involved in seeking to apply the laws of several different countries. The

\footnotetext{
72 See Intellectual Property Right and Private International LaW: Heading for the Future 144 (Josef Drexl ed. 2005).

73 HuANG, supra note 33 at 292.

74 Zhonghua Renmin Gongheguo Minshi Susongfa [Civil Procedure Law] art. 22 (1991, revised in 2007).
} 
burden involved in applying numerous different laws falls also upon the court. There is also a kind of absurdity in applying numerous different laws to what is essentially a single wrong perpetrated by a single infringer. Fairness and efficiency and to some degree common sense suggest that one law should govern in such a case. 75

\section{Conclusion}

The enactment of the Private International Law Act has been observed by many Chinese scholars as a benchmark that China has systemized and modernized its conflict rules. ${ }^{7}$ In the field of tort, the improvement is reflected in the following two aspects. First, the Private International Law Act provides a more comprehensive choice-of-law system of tort which includes not only the main rules on torts, but also particular rules for certain specific torts. Second, strongly influenced and much inspired by modern foreign and international legislation, the Private International Law Act abolishes the out-dated rules and incorporates a number of advanced doctrines that have been developed in western legal system.77

Nonetheless, Chinese private international law is still in a period of transition, as the progress represented by the enactment of the Private International Law Act is but "an imperfect improvement." 78 There is still a long way for China to go towards accomplishing the task of building a modern, mature private international law system. The current crossroads at which Chinese private international law finds is graphically illuminated by the legislative development of torts conflicts. Notwithstanding the significant improvement, the rules contained in the Private International Law Act are fraught with various defects. For this reason, the statutory reform of the tort conflicts in China may be compared to "two steps forward, one step back."

After providing a thorough introduction and systematic review of the statutory reform of torts conflicts that has happened in China, the author now summarizes the problems that have surfaced in this process, and puts forward the corresponding suggestions. It is the author's hope that these suggestions will be helpful to Chinese authorities in improving the legislation in the future, which both China and foreign countries would stand to benefit from. Bonomi \& Gian Paolo Romano eds. 2010).

77 Huo, supra note 3 , at 1092.

78 Id. at 1063-1093. 


\section{A. The Main Rules on Tort}

As analyzed in Part III A, the main rules on tort reflected in Article 44 of the Private International Law Act are problematic in three points. First, habitual residence lacks an objective definition. Second, the rationality of an automatic preference to the law of the common habitual residence over the lex loci delicti is open to doubt. Third, there is little, if any, practicability to introduce the notion that the parties to a tort may choose the applicable law after the tort has happened. In this light, the author puts forward the following suggestions.

First of all, the Supreme's People's Court should spell out the precise meaning of habitual residence to close the statutory loophole. ${ }^{79}$ Though the existing Chinese legislation prior to the Private International Law Act does not contain the expression of habitual residence, a similar term, i.e., "constant residing place" has been used by the Chinese law. 80 For instance, Article 15 of the GPCL provides that (1) the domicile of a person shall be the place where his household is registered ("huji");81 (2) where his constant residing place is different from the place of his household registration, his constant residing place shall be regarded as his domicile." 82 Moreover, in the Opinions on GPCL, the Supreme People's Court interprets in Article 9 that the constant residing place of a person is the place inhabited continuously by him for more than one year after he left his domicile, except the case of hospitalization. 83 Given that there is no material difference between the two terms, and that the Chinese judges have been familiar with the definition of constant residing place, the author suggests that the Supreme's People's Court should state that habitual residence has the same meaning as constant residing place. In view of the vital importance of habitual residence throughout

79 According to the Law on the Organization of the People's Court, the Supreme People's Court has the authority to give judicial interpretation under the following two circumstances: (1) the Supreme People's Court can provide interpretation when it actually tries a case, if there is a request for interpretation submitted from a Higher People's Court; and (2) when a new Act is enacted, the Supreme People's Court is entitled to give a general interpretation about how the legislation should be implemented in adjudication. See Lin, supra note 6, at 221.

80 In Chinese, habitual residence is pronounced as 'jingchang jusuo,' while constant residing place as 'jingchang juzhudi.'

81 'Huji' or 'hukou' is a unique term used in China, which is usually translated as 'household registration.' A household registration record officially identifies a person as a resident of an area and includes identifying information such as the name of the person, date of birth, the names of parents, and name of spouse, if married. The modern household registration system dates back to 1958 when the Chinese government began using it to control the movement of people between urban and rural areas. Individuals were broadly categorized as a 'rural' or 'urban' worker. A worker seeking to move from the country to urban areas to take up non-agricultural work would have to apply through the relevant bureaucracies. There were controls over education, employment, social welfare and so on. See Xiandai Hanyu Cidian [Modern Chinese Dictionary] 535 (China Academy of Social Sciences ed., 2004).

82 GPCL, supra note 4, art.15.

83 For the opinions on GPCL, see supra note 7, art. 9. 
the Private International Law Act, the author argues that the Supreme People's Court should interpret the meaning of habitual residence as soon as possible.

Second, as the automatic preference to the law of the common habitual residence over that lex loci delicti is not always justified, it is submitted that Article 44 of the Private International Law Act should restore the alternative reference rule employed by Article 146 of the GPCL in this context. To be more specific, where the parties have their habitual residence in the same country, the tort liability may be governed by the law of that country [Emphasis added]. As noted earlier, the principle of closest connection has been established as a supplementary rule to determine the applicable law by Article 2(2) of the Private International Law Act. Judges are, therefore, entitled to choose a law between the lex loci delicti and the law of common habitual residence depending on the judgment which one is more closely connected with the tort liability.

Third, insofar as the parties can hardly reach an agreement on the applicable law after the tort has happened, the introduction of party autonomy by Paragraph Three of Article 44 is highly debatable. In the author's opinion, if the Chinese legislators do intent to introduce party autonomy into the field of tort in order to promote predictability and efficiency, they should permit the parties to choose the law governing not only their contract but also the tort liability which would not have occurred but for that contract. Many arguments can be made in support of application of the law chosen by the parties under such a circumstance. First, it is convenient to have all issues which arise out of what is essentially a single relationship governed by one law. Second, and more importantly, application of the law chosen by the parties is in conformity with the parties' expectations or intentions. In the practice of international business, the parties often agree that the law chosen by them will govern all disputes between them which arise in connection with the contract. Indeed, it is unrealistic to assume that the nonlawyers understand the distinction between contract and tort. 84 Even if this distinction were appreciated, it is also inconceivable that the parties would expect another law to apply to tort which arises out of the contract, and they may well have relied on the assumption that the same law covers both types of liabilities. Third, application of the law chosen by the parties to the contract to tort liability can increase uniformity of decisions. As "the parties can choose the law governing their contract" is a universally accepted principle, the same law will be applied regardless of whether an issue which arises out of a contractual relationship is characterized as one of contract or tort. Last, but not least, the worry that allowing pre-tort agreement would put the weaker party in danger is unnecessary, insofar as Article 58 (3) of the GPCL states unambiguously that civil acts performed by a person against his true intentions as a result of cheating,

84 See Restitution and the Conflict of Laws 124 (Francis Rose ed.1995). 
coercion or exploitation of his unfavorable position by the other party shall be null and void. 85 Under the Chinese scholarship and judicial practice,, 86 this is a mandatory rule, which, therefore, should be applicable to foreign-related civil relationships directly irrespective of the applicable law. .7 In the light of all above analysis, the author submits that the suggested choice-of-law rules for tort in general are:

The laws applicable to tort liability shall be the law of the country in which the tortious act is committed. However, where the parties concerned have their habitual residence in the same country, the tort liability may be governed by the law of that country. Where the tort occurred in the performance of a commercial contract between the parties, the law chosen by the parties to govern the contract shall also govern the tort liability between them which arise in connection with the contract.

\section{B. Particular Torts}

After the implementation of the Private International Law Act, particular choice-of-law rules for certain specific torts are scattered among the three different acts: the Maritime Act, the Civil Aviation Act and the Private International Law Act. Since the Maritime Act and the Civil Aviation Act have been existed for nearly two decades which are unaffected by the Private International Law Act, this section will focus on the new rules incorporated by the Private International Law Act.

As analyzed in Part III (B), apart from providing conflict rules for torts in general, the Private International Law Act lays down special conflict rules for product liability, internet defamation, and the IPR torts. Considering that those three categories of torts have occurred in China in quantity in recent years, most Chinese scholars argue that the enactment of the rules represents a historic progress. 88

Nevertheless, it should be noted that the progress made by the Private International Law Act in this field is rather limited. As examined above, there are a number of defects or problems with Article 45, Articles 46 and 50, which need to be solved in one way or another. Moreover, the Private International Law Act neglects some other important types of torts which call for special treatment, such as unfair competition, environmental

Article 4 of the Private International Law Act introduces the notion of 'Mandatory Rules,' which in view of its legislative purpose may not be derogated from, even if a law of another country is designated as the applicable law. This article provides that: "The laws of the People's Republic of China which are mandatorily applicable to foreignrelated civil relationships shall be applied directly." See Private International Law Act, supra note 1, art. 4.

88 HuAnG, supra note 33 , Preface. 
pollution, nuclear damage and traffic accidents, despite the scholars' calls. 89

Indeed, as early as in the late 1990s, when the Chinese Society of Private International Law drew up the "Model Law of Private International Law of the People's Republic of China" (hereinafter the Model Law) which was expected to serve as a blueprint for the NPC's Standing Committee to enact the Private International Law Act, the scholars have reach a consensus on the pressing need to enact particular rules for those specific categories of torts. Therefore, the Model Law contains specific choice-oflaw rules for not only product liability, internet defamation, IPR torts but also unfair competition, environmental pollution, nuclear damage, and traffic accidents. 90 The judicial practice during the past decade has shown that there is greater need to enact particular rules for those special torts. Hence, the scholars advocated that the Private International Law Act should include those rules to establish a systematic and elaborate regime of tort conflicts and to meet the demand of judicial practice.91 Unfortunately, such suggestion was rejected by the legislators for reasons unknown.

Because the Private International Law Act has been newly enacted, it is improbable for the Chinese legislature to revise it in near future. The author argues that the improvement of the Private International Law Act may take two steps. First, the Supreme' People's Court should interpret the Private International Law Act as soon as possible, so that minor defects of the rules contained in the Private International Law Act can be overcome. Second, in the long run, when the judicial interpretation cannot satisfy the judicial practice any longer, the National People's Congress should revise the Private International Law Act substantively to build a modern, sophisticated system of private international law in a real sense. 92

Chinese Society of Private International Law, Model Law of Private International Law of the People's Republic of China 152-161 (2000). For an English version, see 3 Y.B. Private Int' L L. 349-390 (Petar Sarczvic \& Paul Volken eds. 2001).

90 Id. arts. 121-124.

91 Yuan Quan, Helan Qinquanxingwei Zhunjufa de Xinfazhan, Jianlunqidui Woguo Guojisifalifa de Jiejian Zuoyong [New Development of Tort Conflicts: With Reference to the Legislation of Chinese Private International Law] 4 ZhongGuo GuojISIFA Yu BiJAofa Niankan [ChineSe Y.B. PRIvate InT' L L. \& Comp. L.] 234 (2001).

92 Huo, supra note 3, at 1092-1093. 